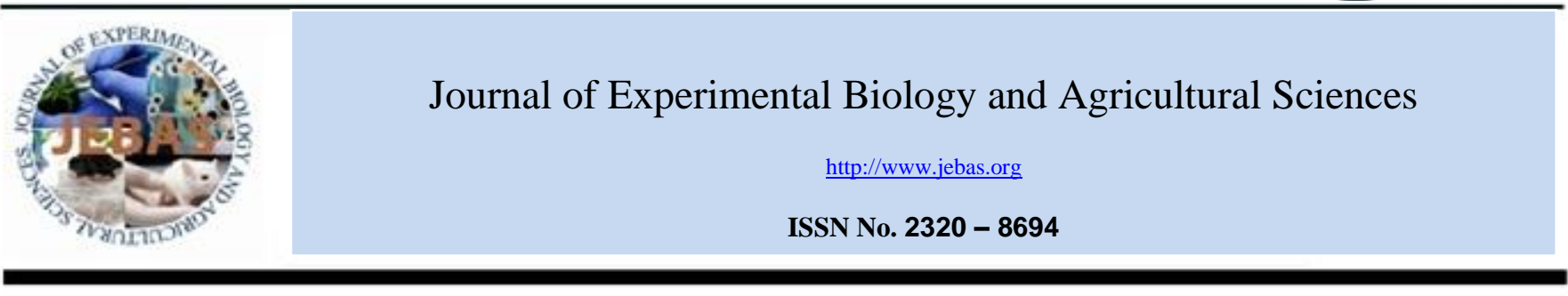

\title{
ASSOCIATION OF VITAMIN D RECEPTOR GENE POLYMORPHISMS AND GESTATIONAL DIABETES IN SAUDI WOMEN
}

\author{
Archana P. Iyer ${ }^{1,2,}$, Susan Lanham New ${ }^{3}$, Sawsan Khoja ${ }^{1,2}$, Maryam A. Al-Ghamdi ${ }^{1,2}$ \\ ${ }^{1}$ Department of Biochemistry, King Abdulaziz University, Jeddah, Saudi Arabia \\ ${ }^{2}$ Vitamin D Pharmacogenomics Research Group, King Abdulaziz University, Jeddah, Saudi Arabia \\ ${ }^{3}$ Health and Medical Sciences College, Department of Nutrition and Metabolism, University of Surrey, United Kingdom
}

Received - May 12, 2017; Revision - June 17, 2017; Accepted - June 29, 2017

Available Online - June 30, 2017

DOI: http://dx.doi.org/10.18006/2017.5(3).282.287

\section{KEYWORDS \\ Gestational diabetes mellitus \\ Gestational diabetes \\ Vitamin D receptor gene \\ Saudi Arabia}

Polymorphism

\section{ABSTRACT}

Vitamin D is primarily associated with a major role in bone formation. It is also associated with onset and progniosis of diseases such as diabetes, cancer and cardiovascular diseases. In Saudi Arabia, the prevalence of $\mathrm{DM}$ is one of the highest reported in the world. There is accumulating evidence suggesting an association between the DM and vit D deficiency. This study was proposed to establish a possible correlation between gestational diabetes mellitus (GDM) and the polymorphisms in the vitamin D receptor (VDR) gene at the sites namely TaqI, BsmI, and ApaI. Results of this study revealed that homozygous recessive genotype $t$ of the TaqI site with GDM. This study will help to establish the role of VDR gene in occurrence of various subsets of DM which is a major metabolic disorder in Saudi Arabia.
* Corresponding author

E-mail: arch729@gmail.com (Archana P. Iyer)

Peer review under responsibility of Journal of Experimental Biology and Agricultural Sciences.

Production and Hosting by Horizon Publisher India [HPI] (http://www.horizonpublisherindia.in/).

All rights reserved.
All the article published by Journal of Experimental Biology and Agricultural Sciences is licensed under a Creative Commons Attribution-NonCommercial 4.0 International License Based on a work at www.jebas.org.

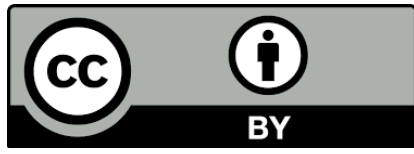




\section{Introduction}

Gestational diabetes is one of the most frequent conditions associated with diabetes causing severe maternal and neonatal complications (Blumer et al., 2013). The frequency of Gestational diabetes mellitus (GDM) usually reflects the frequency of type 2 diabetes in the underlying population. Women who have a history of GDM are at a higher risk for subsequent type 2 diabetes (Moses, 2012). There are many complications related to DM such as dehydration, weakness and fatigue, vaginal or penile yeast infection, weight loss, blurred vision and confusion. Long-term complications are categorized into two types viz microvascular and macrovascular. The microvascular relate to the small blood vessels and capillaries and lead to kidney, eye, and nerve disease (Hapo study, 2008). While, macrovascular complications relate to disease of medium-sized and large blood vessels and lead to heart attacks, circulation problems in the legs, and strokes (Masharani, 2008). GDM is a major health concern affecting a great share of pregnancies, with complications arising from abnormally high blood glucose levels (American Diabetes Association, 2011). According to the recommendation of the World Health Organization (WHO), increased blood glucose levels in pregnancy are termed as gestational diabetes or diabetes mellitus (WHO, 2013). During maternal diabetes, fetal insulin levels are increased that promote the storage of excess energy as fat and act as a growth factor and causing macrosomia (Dabelea et al., 2000). Mothers with GDM have up to $50 \%$ chance of developing T2DM within 5 years of delivery.

Vitamin D (Vit D) plays a major role in the development and maintenance of bone tissue, and also in maintaining normal homeostasis of calcium and phosphorus. Recently, various reports have shown the relationship between metabolic syndrome and deficiency of vitamin D (Wimalawansa, 2016).

Further, 1,25-Dihydroxyvitamin $\mathrm{D}_{3}\left[1,25(\mathrm{OH})_{2} \mathrm{D}_{3}\right]$ also plays a major role in affecting components of the immune system (Holick, 2002). Vit D is obtained both through dietary intake (10-20\%) as well as cutaneous synthesis on exposure to sunlight (80-90\%) (Rizzoli \& Bonjour, 2004). Vit $\mathrm{D}_{3}$ or cholecalciferol, and vitamin $\mathrm{D}_{2}$ or $\mathrm{D}_{3}$ is hydroxylated in the liver, leading to formation of 25-hydroxyvitamin $\mathrm{D}$ or $25(\mathrm{OH}) \mathrm{D}$, which is the chief form in circulation. $25(\mathrm{OH}) \mathrm{D}$ is then hydroxylated in kidney with the aid of $1 \alpha$-hydroxylase forming the biologically active, dihydroxylated form of vit $\mathrm{D}$, calcitriol or $1,25(\mathrm{OH})_{2} \mathrm{D}$, which acts through specific vit $\mathrm{D}$ receptors to regulate calcium metabolism and the differentiation of various cell types.

The genomic action of vitamin $\mathrm{D}$ is expressed through the vitamin D receptor (VDR), that shows high degree of polymorphism. The VDR gene is located on chromosome $12 q$ (12-12q14). The expression of VDR is noted in various cells, such as lymphocytes, macrophages, and pancreatic-cells (Pittas et al., 2007). Detailed description of four polymorphic sites have been widely studied. A polymorphic FokI site in exon 2 produces an alternative transcription initiation site, causing the formation of a different protein with three amino acids being added to the amino terminus. Polymorphic BsmI and ApaI sites are present in intron 8 , and a silent $\mathrm{T}$ to $\mathrm{C}$ substitution creates a TaqI restriction site in exon 9 (Rostand, 1979). Investigations on association between some VDR gene polymorphisms and DM have shown that they influence susceptibility to DM in many populations (Dawson-Hughes et al., 2005; Jones et al., 2007). It has been well established that a length of the VDR, affected by the presence of the polymorphisms, could result in lower activation of target cells, as a longer VDR protein seems to have a decreased transcriptional activity (Baroncelli et al., 2008; Mithal et al., 2009).

The aim of the present study was to look for a possible correlation between polymorphisms in the VDR gene and occurrence of GDM in Saudi women. The study will help in understanding the molecular mechanism of interaction between vit $\mathrm{D}$ status and gestational diabetes. This information will help us in designing a pharmacogenomic approach towards treatment of different types of diabetes making it more effective.

\section{Materials and Methods}

\subsection{Sample collection}

Blood samples were collected from 50 pregnant women with normal blood glucose levels, and 50 women with gestational diabetes. All the subjects were well informed and their written consent was taken to participate in the research program. Two sets of fasting blood samples were collected separately from each subject in clot activator and gel tubes (for Glucose and Vit D Total) and Spray-coated $\mathrm{K}_{2}$ EDTA plastic tubes (for DNA extraction). The serum was separated and stored at $-80^{\circ} \mathrm{C}$ until further analysis. Fasting glucose was measured by Dimension Vista ® System (Siemens, Germany). Total vitamin D was estimated using ADVIA Centaur ®immunoassay System (Siemens, USA). DNA extraction was done from whole blood and stored at $-20^{\circ} \mathrm{C}$ till further manipulations.

\subsection{DNA extraction}

Genomic DNA was extracted from whole blood samples, in biosafety cabinet, using QIAamp DNA Blood Mini Kit (QIAGEN, USA,Cat.no.51104). Storage of DNA was at $-20^{\circ} \mathrm{C}$ for PCR amplification. On the other hand, concentration and purity of the extracted DNA was calculated automatically by Nanodrop2000c instrument from Thermo Scientific (USA).

\subsection{Polymerase chain reaction}

For Polymerase Chain Reaction (PCR), the reactions were prepared using Maxima Hot Start Green PCR Master Mix (2X). 
Table 1. The PCR Reaction Components

\begin{tabular}{|c|c|c|}
\hline Component & Final concentration & Quantity \\
\hline Maxima Hot Start Green PCR Master Mix (2X) & $\mathrm{X} 2$ & $1 \mu 25$ \\
\hline Forward Primer $(10 \mu \mathrm{M})$ & $\mathrm{M \mu} 0.2$ & $1 \mu 4$ \\
\hline Reverse Primer $(10 \mu \mathrm{M})$ & $\mathrm{M} \mu 0.2$ & $1 \mu 4$ \\
\hline Template DNA & $1 \mu \mathrm{g}$ & $1 \mu 12$ \\
\hline Water, nuclease-free (R0581) & & \\
\hline Total & & \\
\hline
\end{tabular}

The primers were purchased from Biolegio, Netherlands. The forward primer was (5'-CAA CCA AGA CTA CAA GTA CCG CGT CAG TGA-3') and the reverse primer was (5'-GCA ACT CCT CAT GGC TGA GGT CTC-3'), as used by Uitterlinden et al. (1996). The $100 \mu \mathrm{M}$ stock of these primers was prepared according to the instruction of their company and then $10 \mu \mathrm{M}$ aliquots were prepared by 1:10 dilution with distilled water.

For PCR, Thermo Scientific (Maxima Hot Start Green PCR Master Mix (2X), K1061, USA) was used. The reaction mix $(50 \mu \mathrm{l})$ consisted of $2 \mathrm{X}$ reaction buffer, $4 \mathrm{mM} \mathrm{Mg}^{2+} 4 \mu \mathrm{M}$ deoxyribonucleoside triphosphates, $0.2 \mu \mathrm{M}$ of each primer, Taq DNA polymerase to a concentration of $0.45 \mathrm{U}$ and template DNA concentration of $20 \mathrm{ng}$. and sterile water making up the final volume (Table 1).

The master mix and the sample were divided into the PCR tubes in pre-PCR area before transferring them to the thermal cycler GeneAmp® PCR System 9700 (Model No. N805S3052708) supplied from Applied Biosystem, Japan. The PCR conditions consisted of initial denaturation at $95^{\circ} \mathrm{C}$ for 4 min, followed by 30 cycles of denaturation at $95^{\circ} \mathrm{C}$ for $30 \mathrm{~S}$, annealing temperature of $60^{\circ} \mathrm{C}$ for $1 \mathrm{~min}$, then an extension at $68^{\circ} \mathrm{C}$ for $2 \mathrm{~min}$, followed by a final extension at $72^{\circ} \mathrm{C}$ for $5 \mathrm{~min}$ and final hold at $4^{\circ} \mathrm{C}$.

PCR product was verified by horizontal gel equipment (Model No.48205), and an electrophoresis power supply (Model No.041BR) from Bio-Rad, UK. The visualization of PCR products was carried out by electrophoresis on $1 \%$ agarose gels using 1X TBE buffer. The gel of electrophoresis was prepared using agarose, ethidium bromide promega (USA) and TBE buffer (10X) which were purchased from Thermo Scientific, US. DNA loading dye (R0611) and DNA ladder (SM0314) ranging from 250 to $10,000 \mathrm{bp}$ were used in each run. Gel documentation system (Model No.M03 2746) from UVitec, Cambridge, UK, was used to visualize the PCR product.

\subsection{RFLP analysis of VDR gene polymorphism}

Amplified PCR products $(5 \mu \mathrm{l})$ were digested with $3000 \mathrm{U}$ of each restriction enzyme from Thermo Scientific, USA. These enzymes used for digestion were ApaI, BsmI, and TaqI. These enzymes were used according to the supplier-recommended protocols (Thermo Scientific, US, Canda). In the thermal cycler, the reaction was incubated for 1 hour at $37^{\circ} \mathrm{C}$ being the activation temperature of BsmI and ApaI. Enzyme inactivation was achieved by incubation at $65^{\circ} \mathrm{C}$ for $20 \mathrm{~min}$. This was followed by incubation at $65^{\circ} \mathrm{C}$ for $1 \mathrm{~h}$ to inactivate TaqI, followed by a final step of inactivation at $80^{\circ} \mathrm{C}$ for $20 \mathrm{~min}$. RFLP products were separated on on $2 \%$ agarose gel.

\subsection{Statistical analysis}

All statistical analyses were performed using the MegStat ${ }^{\circledR}$ version 9.0 computer program. Descriptive data were given as mean \pm standard deviation (SD). Differences among groups were tested using the t-test. Mean of data was compared for different alleles and genotypes by analysis of variance (ANOVA). Rare genotypes ( $\mathrm{n}=0$ in any group) were excluded from the analysis. Differences in distribution of the genotypes between the females and males according to T1DM, T2DM, GDM in comparison to control subjects were examined with the chi-square analysis. Differences in genotype frequencies were considered statistically significant for $p$-value $<0.05$.

\section{Results}

The volunteers in this study were classified according to Fasting Blood Glucose (FBG) test as two groups viz normal pregnant and GDM. The study group consisted of 50 pregnant women with normal blood glucose levels and 50 women with GDM. Result of study revealed that vit D levels in normal pregnant women was $38.32 \pm 18.37 \mathrm{nmol} / \mathrm{ml}$, while in pregnant women with GDM, the levels were as low as $10.89 \pm 8.95$ $\mathrm{nmol} / \mathrm{ml}$ with a significant $p$ value of $<0.01$. The percentage vit $\mathrm{D}$ deficiency in normal women was $30 \%$ while in women with GDM, it was as high as $87 \%$ with a significant $p$ value of $<0.01$.

The PCR products of the samples collected from Saudi volunteers, $\sim 2229$ bp as shown in Figure 1, were digested with the BsmI, TaqI, and ApaI restriction enzymes. The allele frequencies for all three sites in control and GDM patients are represented in table 3 and 4 respectively. During study no significant difference was reported in the distribution of alleles at ApaI and BsmI site between the two groups. Further, it was observed that the homozygous recessive genotype tt was higher accounting for $66 \%$ in GDM patients when compared to the control subjects. 
Table 2. Clinical and biochemical characteristics of gestational diabetic women and controls.

\begin{tabular}{|l|lll|}
\hline Parameters & Normal pregnant women & Gestational diabetic women & $P$-value \\
\hline & Mean \pm SD $(\mathrm{n}=50)$ & Mean \pm SD $(\mathrm{n}=50)$ & 0.104 \\
\hline Age $($ years) & $29 \pm 5.17$ & $32 \pm 6.29$ & 0.042 \\
\hline Weight $(\mathrm{Kg})$ & $69.18 \pm 14.94$ & $81.09 \pm 27.89$ & 0.075 \\
\hline BMI & $28.09 \pm 5.31$ & $32.21 \pm 5.85$ & 0.858 \\
\hline Gestational weeks & $29.32 \pm 6.2$ & $29.57 \pm 5.97$ & 0.000 \\
\hline GCT $(\mathrm{mmol} / \mathrm{L})$ & $6.4 \pm 1.46$ & $9.96 \pm 2.03$ & 0.000 \\
\hline GTTF $(\mathrm{FBS})(\mathrm{mmol} / \mathrm{L})$ & $4.29 \pm 0.66$ & $5.32 \pm 0.71$ & 0.000 \\
\hline GTT1 $(\mathrm{mmol} / \mathrm{L})$ & $7.61 \pm 1.42$ & $11.45 \pm 1.28$ & 0.000 \\
\hline GTT2 $(\mathrm{mmol} / \mathrm{L})$ & $6.57 \pm 1.22$ & $10 \pm 1.26$ & 0.01 \\
\hline Vit D $(\mathrm{nmol} / \mathrm{L})$ & $38.32 \pm 18.37$ & $10.89 \pm 8.95$ & - \\
\hline Positive History of diabetes $\%$ & $54 \%$ & $14 \%$ & - \\
\hline Negative History of diabetes $\%$ & $30 \%$ & $6 \%$ & - \\
\hline Unknown History of diabetes $\%$ & $16 \%$ & $80 \%$ & \\
\hline
\end{tabular}

Values are mean $\pm S D$. BMI, Body mass index; GCT, Glucose challenge test; GTTF, Glucose tolerance test fasting; FBS, Fasting blood sugar; GTT1, Glucose tolerance test after 1 hour; GTT2, Glucose tolerance test after 2 hour; *Highly significant difference ;Values represented as the mean \pm standard deviation (SD); $P$ Value for control and GDM group.

\section{Discussion}

GDM is a major health concern in pregnant women. Around the world, 1-20\% prevalence of GDM has been reported, on par with obesity and type 2 diabetes mellitus (T2DM) (American diabetes association, 2011). DM is a group of metabolic disorders which is characterized by a chronic hyperglycemic condition resulting from defects in insulin secretion, insulin action or both. Although many studies have been carried out on the VDR gene and its association with various types of diabetes, the results seem to be highly population dependent (Iyer et al., 2017). Our study has clearly shown that the recessive $t$ allele at TaqI site is associated with the prognosis of GDM. A similar study carried out on Saudi population by Tawfeek et al. (2011), analyzed the polymorphism at the BsmI site on the VDR gene and found no correlation between vitamin D and GDM. Another study conducted on Iranian population by Aslani et al. (2011) on FokI polymorphism of the VDR gene clearly found a significant association between the $\mathrm{F}$ allele and prevalence of GDM. Further, they found that people who possessed the F allele had decreased incidence of gestational diabetes. In contrast to this result, the present study clearly indicates a role of the recessive $t$ allele in development of GDM. Bid et al. (2009) performed a study on the same sites on an Indian population and did not report any association between the VDR gene polymorphism and type II diabetes. The fact that there are discrepancies between various studies could be attributed to the variation in gene pool among various ethnic groups in the VDR gene loci. Genetic and environmental interactions could also play a major role in the prognosis of diabetes.

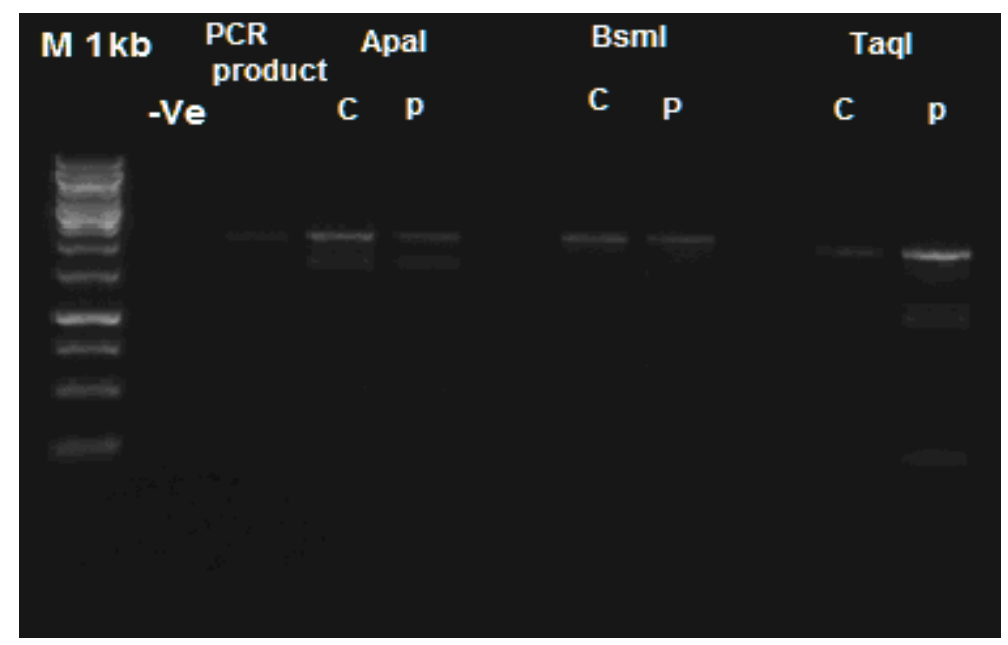

Figure 1: Photograph of a 1\% agarose gel showing the results of three restriction enzymes ApaI, BsmI, TaqI and FokI digestion. Lane

M: DNA marker. Lane 2 and 3: negative controls and PCR products yielded one band of size $2229 \mathrm{bp}$. Lane 4, 5, 6, 7, and 8 comparisons between three restriction enzymes ApaI, BsmI, TaqI according to GDM (P) and the control subjects $(C)$. 
Table 3. Distribution of various alleles in control subjects

\begin{tabular}{|l|l|ll|}
\hline Restriction site & Genotype & Number of samples & \% frequency \\
& $\mathrm{AA}$ & 18 & 36 \\
\cline { 2 - 4 } & $\mathrm{Aa}$ & 20 & 40 \\
\cline { 2 - 4 } & $\mathrm{aa}$ & 12 & 24 \\
\cline { 2 - 4 } & & $(50$ total $)$ & $(100 \%$ total $)$ \\
\hline $\boldsymbol{B s m I}$ & $\mathrm{BB}$ & 20 & 40 \\
\cline { 2 - 4 } & $\mathrm{Bb}$ & 14 & 28 \\
\cline { 2 - 4 } & $\mathrm{bb}$ & 16 & $(100 \%$ total $)$ \\
\hline & & $(50$ total $)$ & 40 \\
\hline TaqI & $\mathrm{TT}$ & 20 & 30 \\
\cline { 2 - 4 } & $\mathrm{Tt}$ & 15 & 30 \\
\hline & $\mathrm{tt}$ & 15 & $(100 \%$ total $)$ \\
\hline
\end{tabular}

Table 4. Distribution of various alleles in GDM patients.

\begin{tabular}{|llll|}
\hline Restriction site & Genotype & Number of samples & \% frequency \\
& $\mathrm{AA}$ & 12 & 24 \\
\cline { 2 - 4 } & $\mathrm{Aa}$ & 16 & 32 \\
\cline { 2 - 4 } & $\mathrm{aa}$ & 22 & 44 \\
\cline { 2 - 4 } & & $(50$ total $)$ & $(100 \%$ total $)$ \\
\hline BsmI & $\mathrm{BB}$ & 11 & 22 \\
\cline { 2 - 4 } & $\mathrm{Bb}$ & 17 & 34 \\
\hline & $\mathrm{bb}$ & 22 & 44 \\
\hline TaqI & $(50$ total $)$ & 18 \\
& $\mathrm{TT}$ & 9 & 16 \\
\hline $\mathrm{Tt}$ & 8 & 66 \\
\hline $\mathrm{tt}$ & 33 & $(100 \%$ total $)$ \\
\hline & & $(50$ total $)$ & 18 \\
\hline
\end{tabular}

\section{Conclusions}

In this study, significant differences in vit D level were reported between pregnant women with normal blood glucose levels and diabetic women. Further, it was reported that people with lower than required levels of vitamin $\mathrm{D}$ serum levels are more prone to becoming diabetic. When considering the VDR gene polymorphisms, we found that the t allele of the TaqI polymorphic site was associated with increased risk of GDM. Both these findings are very important milestones in developing a pharmacogenomic approach towards treatment of diabetes. Unfortunately, the sample size of the study is small and hence we recommend that the study be extended to a larger population to arrive at a clearer picture.

\section{Acknowledgement}

This project was funded by the Deanship of Scientific Research (DSR), King Abdulaziz University, Jeddah, under grant no. RG-8-130-36. The authors, therefore, acknowledge with thanks DSR for technical and financial support.

\section{Conflict of interest}

Authors would hereby like to declare that there is no conflict of interests that could possibly arise.

\section{References}

American Diabetes Association (2011) Diagnosis and classification of diabetes mellitus. Diabetes Care 34 :S62-S69.

Aslani S, Nezhad A, Mirzaei K, Maghbooli Z, Afshar A, Karimi F (2011) VDR FokI polymorphism and its potential role in the pathogenesis of gestational diabetes mellitus and its complications. Gynaecological Endocrinology 27: 1055-1060 DOI:10.3109/09513590.2011.569786.

Baroncelli GI, Bereket A, El Kholy M, Audì L, Cesur Y, Ozkan B, Rashad M, Fernández-Cancio M, Weisman Y, Saggese G, Hochberg ZE (2008) Rickets in the Middle East: role of environment and genetic predisposition. The Journal of 
Bid HK, Konwar R, Aggarwal CG, Gautam S, Saxena M, Nayak VL, Banerjee M (2009) Vitamin D receptor (FokI, BsmI and TaqI) gene polymorphisms and type 2 diabetes mellitus: a North Indian study. Indian Journal of Medical Sciences 63: 187-194. DOI: 10.4103/0019-5359.53164.

Blumer I, Hadar E, Hadden DR, Jovanovič L, Mestman JH, Murad MH, Yogev Y (2013) Diabetes and pregnancy: an endocrine society clinical practice guideline. The Journal of Clinical Endocrinology \& Metabolism 98:4227-4249. doi: 10.1210/jc.2013-2465.

Dabelea D, Hanson RL, Lindsay RS, Pettitt DJ, Imperatore G, Gabir MM, Roumain J, Bennett PH, Knowler WC (2000) Intrauterine exposure to diabetes conveys risks for type 2 diabetes and obesity: a study of discordant sibships. Diabetes 49 2208-2211. DOI: https://doi.org/10.2337/diabetes.49.12.2208.

Dawson-Hughes B, Heaney RP, Holick MF, Lips P, Meunier PJ, Vieth R (2005) Estimates of optimal vitamin D status. Osteoporosis International 16:713-716. doi:10.1007/s00198005-1867-7.

HAPO Study Cooperative Research Group (2008) Hyperglycemia and adverse pregnancy outcomes. The new England Journal of Medicine 358:1991-2002. DOI: 10.1056/NEJMoa0707943.

Holick M (2002) Vitamin D: the underappreciated D-lightful hormone that is important for skeletal and cellular health. Current Opinion in Endocrinology, Diabetes and Obesity 9:8798 .

Iyer AP, Lanham-New S, Khoja S, Al-Ghamdi MA, Bahlas S (2017) Association of Apa I polymorphism of vitamin D receptor gene with type 2 diabetes mellitus in Saudi

population. Journal of Experimental Biology and Agricultural Sciences 5 : 271-276. DOI: http://dx.doi.org/10.18006/2017.5(2).271.276.

Jones G, Horst R, Carter G, Makin HLJ (2007) Contemporary diagnosis and treatment of vitamin D-related disorders. Journal of Bone Mineral Research 22:V11-V15. doi: 10.1359/jbmr.07s219.

Masharani U (2008) Diabetes Demystified: A Self-Teaching Guide. McGraw-Hill Publishing. Available on
Mithal A1, Wahl DA, Bonjour JP, Burckhardt P, DawsonHughes B, Eisman JA, El-Hajj Fuleihan G, Josse RG, Lips P, Morales-Torres J; IOF Committee of Scientific Advisors (CSA) Nutrition Working Group (2009) Global vitamin D status and determinants of hypovitaminosis D. Osteoporosis International. 20:1807-1820. doi: 10.1007/s00198-009-0954-6.

Moses RG. Gestational diabetes mellitus: implications of an increased frequency with IADPSG criteria. Diabetes Care 35:461-462. doi: 10.2337/dc11-2237.

Pittas AG, Harris SS, Stark PC, Dawson-Hughes B (2007) The effects of calcium and vitamin D supplementation on blood glucose and markers of inflammation in nondiabetic adults. Diabetes Care 30:980-986. DOI: https://doi.org/10.2337/dc061994.

Rizzoli R, Bonjour J (2004) Dietary protein and bone health. Journal of Bone and Mineral Research 19:527-531. DOI: 10.1359/JBMR.040204.

Rostand SG (1997) Ultraviolet light may contribute to geographic and racial blood pressure differences. Hypertension 30:150-156. DOI: https://doi.org/10.1161/01.HYP.30.2.150

Tawfeek MA, Habib SA, Saultan EM (2011) Vitamin D receptor BsmI gene polymorphisms and gestational diabetes mellitus: A Saudi study. British Journal of Medicine and Medical Research $1:$ 459-468.

Uitterlinden AG, Pols HA, Burger H, Huang Q, Van Daele PL, Van Duijn CM, Hofman A, Birkenhäger JC, Van Leeuwen JP (1996) A large-scale population-based study of the association of vitamin $\mathrm{D}$ receptor gene polymorphism with bone mineral density. Journal of Bone and Mineral Research 11: 1241-1248.

Wimalawansa SJ (2016) Associations of vitamin D with insulin resistance, obesity, type 2 diabetes, and metabolic syndrome. The Journal of Steroid Biochemistry and Molecular Biology 2016. https://doi.org/10.1016/j.jsbmb.2016.09.017.

World Health Organization (2013) Diagnostic criteria and classification of hyperglycaemia first detected in

pregnancy. Available from: http: //130.14.29.110/books/NBK169024 access on 13 December 2015. 